ENDODONTSKO LEČENJE STALNOG PRVOG DONJEG KUTNJAKA SA ENTOMOLARNIM KORENOM: PRIKAZ SLUČAJA I PREGLED LITERATURE

\title{
ENDODONTIC TREATMENT OF THE PERMANENT MANDIBULAR FIRST MOLAR WITH A RADIX ENTOMOLARIS: A CASE REPORT AND LITERATURE REVIEW
}

\author{
Iztok Štamfelj ${ }^{1,2}$, Lea Sušek ${ }^{3}$, Lucija Strmšek $^{1}$ \\ ${ }^{1}$ ODELJENJE BOLESTI ZUBA I MORFOLOGIJE ZUBA, MEDICINSKI FAKULTET, UNIVERZITET U LJUBLJANI, LJUBLJANA, \\ SLOVENIJA \\ ${ }^{2}$ ODELJENJE OPERATIVNE STOMATOLOGIJE I ENDODONCIJE, UNIVERSITI MEDICAL CENTER LJUBLJANA, LJUBLJANA, \\ SLOVENIJA \\ ${ }^{3}$ CENTAR ZA JAVNO ZDRAVLJE PTUJ, PTUJ, SLOVENIJA
}
${ }^{1}$ DEPARTMENT OF DENTAL DISEASES AND DENTAL MORPHOLOGY, FACULTY OF MEDICINE, UNIVERSITY OF LJUBLJANA, LJUBLJANA, SLOVENIA
${ }^{2}$ DEPARTMENT OF OPERATIVE DENTISTRY AND ENDODONTICS, UNIVERSITY MEDICAL CENTRE LJUBLJANA, LJUBLJANA, SLOVENIA
${ }^{3}$ COMMUNITY HEALTH CENTRE PTUJ, PTUJ, SLOVENIA

Sažetak

Uvod: Uspeh endodontskog lečenja zuba temelji se na pravilnom utvrđivanju broja korenova $i$ korenskih kanala. Zbog toga, varijante u broju korenova i broju zuba predstavljaju stalan terapijski izazov. Stalni mandibularni prvi molar (SMPM) obično ima mezijalni koren sa dva kanala i distalni koren sa jednim ili dva kanala, ali može imati i prekobrojni koren koji je postavljeni distolingvalno - radix entomolaris(RE).

Opis slučaja: Novije studije ukazuju da RE uvek sadrži jedan korenski kanal. Iako se RE pojavljuje relativno retko kod ljudi bele rase, može biti uzrok endodontskog neuspeha ako se ne identifikuje pre ili za vreme lečenja. Poznavanje lokacije dodatnog otvora kanala korena će rezultirati modifikacijom u dizajnu pristupnog kaviteta. Štaviše, morfološke karakteristike RE u smislu zakrivljenosti i nagiba korena moraju se uzeti u obzir prilikom pripreme korena kanala da bi se izbegle proceduralne greške, kao što su ispravljanje obodne ivice kanala korena, perforacija ili lomljenje instrumenta.

Zaključak: Ovaj rad predstavlja ponovljeno endodontsko lečenje SMPM kod pacijenta bele rase i naglašava značaj temeljnog radiografskog $i$ kliničkog pregleda.

Ključne reči: stalni prvi mandibularni molar, terapija kanala korena, prekobrojni koren, anatomske varijante, morfologija

\section{Corresponding author:}

Assistant ProfessorIztok Štamfelj, DMD, MSc, $P h D$

Department of Dental Diseases and Dental Morphology

Faculty of Medicine, University of Ljubljana

Hrvatskitrg 6SI-1000 Ljubljana, Slovenia

e-mail address: iztok.stamfelj@mf.uni-lj.si

telephone (office): 0038615224372

fax:0038615222504
Abstract

Introduction:The success of endodontic treatment is based on correct determination of the number of roots and root canals. Therefore, variants in root number and root canal number are a constant therapeutic challenge. The permanent mandibular first molar (PMFM) usually has a mesial root with two canals and a distal root with one or two canals, but may also have a supernumerary root located distolingually - a radix entomolaris (RE).

Case raport:Recent studies have shown that $R E$ invariably contains a single root canal. Although $R E$ occurs with a relatively low prevalence in Caucasian patients, it may be the cause of endodontic failure if not identified before or during the treatment. The knowledge about the location of the additional root canal orifice will result in a modified access cavity design. Moreover, morphological features of the RE in terms of root inclination and curvature must be taken into account during root canal preparation to avoid procedural errors, such as straightening and ledging of the root canal, perforation or instrument fracture.

Conclusion: This paper presents the endodontic retreatment of a PMFM with RE in a Caucasian patient and highlights the importance of a thorough radiographic and clinical examination

Key words: permanent mandibular first molar, root canal therapy, supernumerary root, anatomical variants, morphology

2016 Faculty of Medicine in Niš. Clinic of Dentistry in Niš. All rights reserved / ㄷ 2016. Medicinski fakultet Niš. Klinika za stomatologiju Niš. Sva prava zadržana. 


\section{Uvod}

Uklanjanie celokupnog vitalnog i nekrotičnog pulpnog tkiva i mikroorganizama iz sistema kanala korena je od suštinskog značaja za uspeh endodontskog tretmana. Ovo se može postići samo ako se svi kanali korena temelino očiste i oblikuiu pre trainog punienia kanala korena zuba i hermetičkog zatvarania krunice zuba. Zbog toga, kliničar mora imati detalino znanie o svim varijantama korena koji se mogu naći u svakoj vrsti zuba.

Procenjuje se da stalni mandibularni prvi molar (SMPM) najčešće zahteva endodontski tretman ${ }^{1}$. Većina SMPM ima središnji koren sa dva kanala i distalni koren s jednim ili dva kanala ${ }^{2}$. Jedan koren više može biti rezultat apikalne furkacije mezijalnog ili, ređe, distalnog korena, prisustva prekobrojnih korenova, ili obe pojave zajedno. Prekobrojni koren se obično nalazi sa lingvalne strane distalnog korena i naziva se radix entomolaris (RE). U vrlo retkim slučajevima, prekobrojni koren se nalazi sa bukalne strane i zove se radix paramolaris. Kod SMPM, radix entomolaris je obično dobro razvijen koren, samo malo manji od glavnog distalnog korena. On je često zakrivljen, naročito u bukolingvalnom smeru, a može biti razdvojen ili spojen sa distalnim korenom. RE se može javiti kod svih stalnih donjih molara, ali najređe kod drugog donjeg molara ${ }^{3}$. Osim toga, može se pojaviti i kod prvog i drugog mlečnog molara ${ }^{4}$. Međutim, različite morfološke odlike RE kod različitih molara zahtevaju njihov detaljaniji opis ${ }^{5}$.

Među etničkim grupama postoje razlike u učestalosti SMPM s odvojenim RE. Kod belaca (Holanđani, Finci, Englezi, Nemci), autori su prijavili frekvencije u rasponu od 0,7 do $3,4 \%{ }^{8-11}$, kod Afrikanaca od 2,8 do $3,1 \%{ }^{12-14}$, za Indijce od 4,6 do $13,3 \%{ }^{15,16}$, a za populaciju s mongoloidnim osobinama (američki Indijanaci, Eskimi, Kinezi, Japanci, Tajlanđani) od 5,8 do $32,0 \%{ }^{17-25}$. Osim toga, izgleda da postoji veća učestalost kod obolelih od Turnerovog sindroma nego kod zdravih individua ${ }^{26}$.

Gu i al. ${ }^{6}$ utvrdili su da je prosečno doba pacijenata u vreme ekstrakcije bilo statistički značajno niže (oko 7 godina) za SMPM sa RE-om u odnosu na ove zube koji su imali po dva korena. Razlika u opstanaku zuba sa i bez RE verovatno je povezana sa endodontskim kao i parodontalnim faktorima.

\section{Introduction}

The removal of all vital and necrotic pulp tissue and microorganisms from the root canal system is essential for the success of endodontic treatment. This can only be achieved if all root canals are thoroughly cleaned and shaped before a dense root canal filling and a hermetic coronal seal are made. Therefore, the clinician must have a detailed knowledge of all root variants that can be found in each individualtooth type.

It is estimated that the permanent mandibular first molar (PMFM) most often requires endodontic treatment ${ }^{1}$. The majority of PMFMs have a mesial root with two canals, and a distal root with one or two canals ${ }^{2}$. An increased number of roots can be a result of apical splitting of the mesial or, less often, distal root, presence of a supernumerary root, or both phenomena together. A supernumerary root is usually present on the lingual aspect of the distal root and called the radix entomolaris (RE). In very rare cases, a supernumerary root is positioned on the buccal aspect and called the radix paramolaris. In PMFMs the RE is usually a well-developed root, which is only slightly shorter than the main distal root. It is often curved, especially in a buccolingual direction, and may be separate or nonseparate in relation to the distal root. The RE appears in all permanent mandibular molars; however, least frequently in the second molar ${ }^{3}$. Moreover, it also appears in the first and the second primary mandibular molars ${ }^{4}$. However, various morphological features of the RE in individual molar types warrant a separate description ${ }^{5}$.

Among ethnic groups, there are differences in the frequency of the PMFM with a separate RE. For Caucasians (Dutch, Finns, Englishmen, Germans), authors have reported frequencies ranging from 0.7 to $3.4 \%^{8-11}$, for Africans from 2.8 to $3.1 \%^{12-14}$, for Indians from 4.6 to $13.3 \%{ }^{15,16}$, and for populations with Mongoloid traits (American Indians, Eskimos, Chinese, Japanese, Thai) from 5.8 to $32.0 \%{ }^{17-25}$. In addition, the frequency appears to be greater in individuals affected by Turner syndrome than in healthy individuals ${ }^{26}$.

$\mathrm{Gu}$ et al. ${ }^{6}$ found that the mean age of patients at the time of extraction was statistically significantly lower (by about 7 years) for the PMFM with a RE than for the tworooted variety of this tooth. The diffe- 
Endodontsko lečenje SMPM sa RE često je neuspešno, jer nije bilo radiološke identifikacije i nije bilo lečenja, ili zbog komplikacija koje se javljaju u toku čišćenja i oblikovanja jednog jako zakrivljenog korenskog kanala u RE-u. S druge strane, RE će verovatno biti lokalni faktor koji doprinosi progresiji parodontalne bolesti ${ }^{7}$.

Poznavanje morfoloških odlika i radiološkug prikaza nekog RE bitno je za uspeh endodontskog lečenja, kao i oralnohirurške i parodontlne procedure. Jasno, relativno niska prevalencija RE kod belaca ne umanjuje njegov značaj $u$ kliničkoj stomatologiji. U posljednjih deset godina prijavljeno je nekoliko pojedinačnih ${ }^{27-31}$ i serijskih slučajeva ${ }^{32-34}$ koji ističu važnost identifikacije RE za uspeh endodontskog treatmana kod pacijenata bele rase. Ovaj rad prezentuje reviziju endodontskog lečenja SMPM sa RE i četiri kanala korena. U ovom preglednom radu prikazane su morfoloske odlike i klinicki pristup endodontskom lečenju radix entomolarisa.

\section{Prikaz slucaja}

Ženska osoba stara 47 godina, bele rase, javila se na Odeljenje operativne stomatologije i endodoncije, Univerzitetskog Medicinskog centra u Ljubljani, radi endodontske revizije stalnog levog mandibularnog prvog molara SMPM (zuba 36). Pacijentkinja je navela da je ovaj zub prvi put endodontski lečen oko sedam godina ranije.Tada je posetila svog opšteg stomatologa zbog jakog spontanog bola i intraoralnog otoka, čiji je uzrok bio ovaj zub. Osim toga, imala je osećaj da je zub izdužen, jer se bol pojačavao svaki put pri zatvaranju usta. Nadležni stomatolog je zbrusio krunu zuba i propisao antibiotik azitromicin 500 mg tri dana. Brušenje krune je imalo pozitivan efekat i posle antibiotske terapije, u potpunosti oslobodilo pacijenta svake dalje potrebe za medicinskom negom i stomatologom.

$\mathrm{U}$ trenutku kliničke procene, zub je bio bez simptoma. Krunica se sastojala od velike meziookluzodistalne kompozitne restauracije. Nije bilo reakcije na perkusiju i na palpaciju periapikalne regije. Zub nije reagovao na termičke i električne nadražaje. Nije bilo parodontalnih džepova. Radigrafija periapeksa koju je uradio opšti stomatolog, pokazala je tri nepotpuno napunjena korena, rence in survival of teeth with and without the RE is probably associated with endodontic as well as periodontal factors. Endodontic treatment of the PMFM with the $\mathrm{RE}$ is often unsuccessful because RE was not identified radiographically and was not treated, or due to complications which arise during cleaning and shaping of a severely curved root canal in the RE. On the other hand, the RE is likely to be a local factor that contributes to the progression of periodontal disease ${ }^{7}$.

The knowledge about the morphological features and radiographic appearance of the RE is essential for the success of endodontic treatment as well as for the oral surgical and periodontal procedures. Therefore, a relatively low prevalence of the $\mathrm{RE}$ in the Caucasian population does not diminish its significance in clinical dentistry. In the last decade, several case reports ${ }^{27-31}$ and case series ${ }^{32-34}$ highlighted the importance of the RE identification for the success of endodontic treatment in Caucasian patients. This paper presents endodontic retreatment of a PMFM with an RE and four root canals. Moreover, morphological features of the RE and the clinical approach to its identification and endodontic treatment are reviewed.

\section{Case Report}

A 47-year-old Caucasian female was referred to the Department of Operative Dentistry and Endodontics, University Medical Centre Ljubljana for endodontic retreatment of the left PMFM (tooth 36). The patient reported that approximately 7 years earlier this tooth was endodontically treated for the first time. One month before she visited her general dentist because of severe spontaneous pain and intraoral swelling associated with this tooth. Moreover, she had a feeling of an elongated tooth because the pain intensified each time she closed on the tooth. The referring dentist slightly reduced the crown of the tooth and prescribed her antibiotic azithromycin $500 \mathrm{mg}$ q.d. for three days. According to the patient, reduction of the crown had a distinct palliative effect and after antibiotic therapy the pain completely resolved. The patient's medical and dental histories were noncontributory. At the time of clinical evaluation, the tooth was asymptomatic. The crown was restored with an extensive mesial occlusal distal comp - 
(jedan mezijalni i dva distalna) i veliko rasvetljenje oko vrha mezijalnog korena (slika 1a). Dijagnoza RE bila je asimptomatska, apikalni parodontitis i nedovoljno punjenje Revizija je dovršena u dve posete stomatologu.

Pristupni kavitet je pripremljen, uz prethodno postavljanje koferdama (hygenic Dental Dam Coltène Whaledent, langenau, Nemačka). Operativno polje je dezinfikovano $5 \%$ natrijum hipohloritom. Inspekcija poda pulpne komore otkrila je prisutnost otvora meziolinvalnog (ML), meziobukalnog (MB), distolinvalnog (DL) i distobukalnog (DB) korenskog kanala. Gutaperka je otopljena u eukaliptusovom ulju, a vidljivost korenskih kanala uspostavljena pomoću snimka $\mathrm{K}$ tipa. Korenski kanali su koronarno prošireni i premešteni sa SX datoteke iz ProTaper serije (Dentsply Maillefer, Bal-laigues, Švajcerska). Radne duzine određene su elektronskim putem pomoću AFA Apekslokatora (EIE Analytic Technology, Orange, SAD). Očitavanja DL kanala i DB kanala (u distalnom korenu) bila su 15,0 mm i 16,0 mm (s distalnom ivicom grebena kao referentnom tačkom). Korenski kanali su pripremljeni i ručno pomoću turpije od nerđajućeg čelika koja je prethodno zakrivljena. U toku instrumentacije, korenski kanali su ispirani $2,5 \%$ rastvorom natrijum hipoklorita. Konačno, kanali su osušeni papirnatim poenima, ispunjeni kalcijum hidroksidnom pastom (Calxyl, OCO-Präparate, Dirmstein, Njemačka) i zatvoreni kavitom (Cavit W -3M Deutschland GmbH, Neuss, Nemačka).

Dve nedelje kasnije, zub je još uvek bio bez simptoma, pa je ponovo ispitan pre konačnog punjenja. Korenski kanali su napunjeni pomoću Roeko gutaperka poena (ColtèneWhaledent, langenau, Nemačka), AH Plus punilom (Dentsply De Tray, Konstanz, Nemačka) i hladne lateralne kondenzacije. Postoperativno, početna ortoradijalna projekcija (slika 1b) dopunjena je mezijalnom projekcijom (slika 1c). Poređenjem oba radiograma potvrđeno je prisustvo jednog prekobrojnog korena postavljenog lingvalno. Položaj otvora korenskog kanala bio je tipičan za trokorenu varijantu mandibularnog prvog molara (slika 1d) Definitivna restauracija je izvršena pom oću kompozita osite restauration. There was no discomfort on percussion and on palpation of the periapical area. The tooth did not respond to termic and electric tests. No periodontal pockets were present. A periapical radiograph made by the referring dentist showed three inadequately filled roots (1 mesial and 2 distal roots) and a large radiolucency around the apex of the mesial root (Figure 1a). The diagnosis was asymptomatic apical periodontitis and inadequate obturation was made. The retreatment was completed in two appointments.

The access cavity was prepared and a rubber dam (Hygenic Dental Dam, Coltène Whaledent, Langenau, Germany) was placed in position. The operative field was disinfected with 5\% sodium hypochlorite. Inspection of the pulp chamber floor revealed the presence of mesiolingual (ML), mesiobuccal (MB), distolingual (DL) and distobuccal (DB) root canal orifices. Gutta-percha was dissolved with eucalyptus oil, and patency of the root canals was established using K-type files. The root canals were coronally enlarged and relocated with SX file from the ProTaper series (Dentsply Maillefer, Ballaigues, Switzerland). The working lengths were determined electro-nically using an AFA Apexfinder (EIE Analytic Technology, Orange, USA). Readings for the DL (RE) canal and the DB canal (in the distal root) were $15,0 \mathrm{~mm}$ and $16,0 \mathrm{~mm}$, respectively (with the distal marginal ridge as a reference point). Root canals were prepared manually with precurved stainless steel files. During instrumentation, root canals were irrigated with $2.5 \%$ sodium hypochlorite solution. Finally, the canals were dried with paper points, filled with an interappointment calcium hydroxide dressing (Calxyl, OCOPräparate, Dirmstein, Germany), and sealed with Cavit W (3M Deutschland $\mathrm{GmbH}$, Neuss, Germany).

Two weeks later, the tooth was still asymptomatic and was reaccessed for fthe inal obturation. The root canals were obturated using Roeko guttapercha cones (ColtèneWhaledent, Langenau, Germany), $\mathrm{AH}$ Plus sealer (Dentsply De Tray, Konstanz, Germany) and a cold lateral condensation technique. Postoperatively, the initial orthoradial projection (Figure 1b) was supplemented by a mesialexcentric projection (Figure 1c). Comparison of both radiographs confirmed the presence of a lingually located supernumerary root. The 
(ExciTE $\mathrm{F}$ i Tetric Evo Ceram, location of root canal orifices was also IvoclarVivadent, Schaan, Liech-tenstein). typical for a three-rooted variant of the Šest meseci kasnije, pacijent je kontrolisan. mandibular first molar (Figure 1d). The final Kliničkim ispitivanjem utvrđeno je da je zub restoration was made using a resin composite bio bez simptoma a radiološka kontrola (ExciTE $\mathrm{F}$ and Tetric EvoCeram, Ivoclar pokazala gotovo potpuni nestanak Vivadent, Schaan, Liechtenstein). Six periapeksnog rasvetljenja (slika 1 e).

months later, the patient was recalled for a follow-up. At the clinical examination, the tooth was asymptomatic and the radiographic examination revealed an almost complete resolution of periapical radiolucencies (Figure 1e).
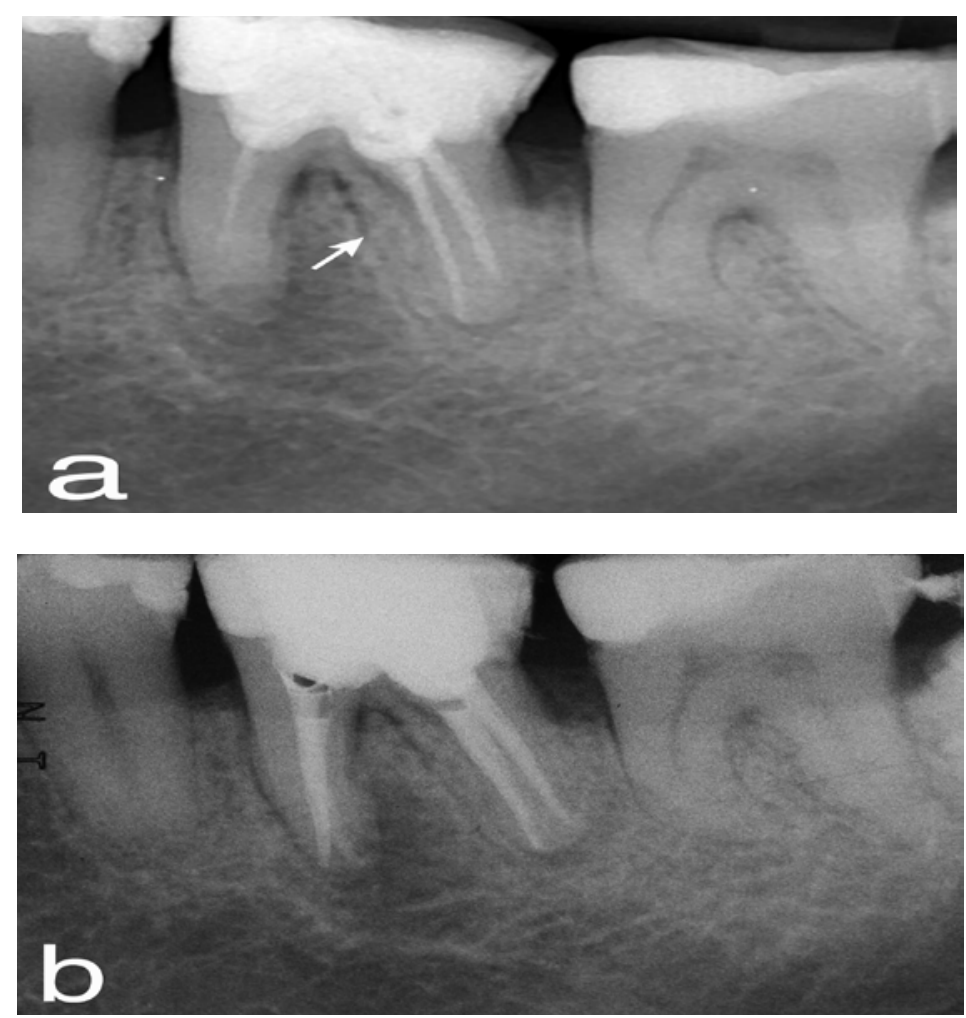

Fig. 1.Prikaz slučaja. a) radiografija, preuzetia od stomatologa, pokazuje desni mandibularni prvi molar sa tri korena skoro jednaka po dužini, neadekvatnim kanalnim punjenjem periopikalnim rasvetljenjem. Slika prekobrojnog korena entomolarnog korena-strelica i distalnog korena se delimično preklapaju. b) Postoperativna ortoradijalna radiografija. c) Postoperativna radiografija sa mezijalnom angulacijom. Poređenem sa Slikama 1A i 1B, entomolarni koren deluje mezijalno postavljen,to jest u pravcu pružanja centralnog znaka. g) slika u ogledalu, izgled pristupnog kvaliteta posle opturacije sva četiri korenska kanala. MB otvor na meziobilnog kanala, ML otvor mezioligvalnog 1 kanala, DB distobukalni kanal u distalnom korenu, DL - otvor na distolingualnog kanala, d) Kanalna radiografija posle šest meseci

Fig. 1.Case presentation. a) A radiograph, taken by the referring dentist, shows the right permanent mandibular first molar with three almost equally long roots, inadequate root canal fillings, and periapical radiolucencies. The images of the supernumerary root radix entomolaris (RE) (arrow) and the distal root partly overlap. b) Postoperative radiograph exposed orthoradially. c) Postoperative radiograph exposed with mesial horizontal angulation. Compared to Figures 1a and 1b, the RE (arrow) appears to have wandered mesially, i.e. in the direction of the shift of the central ray. d) Mirror image of the access cavity after obturation of all four root canals. MB -orifice of the mesiobuccal canal, ML - orifice of the mesiolingual canal, DB - orifice of the distobuccal canal (in the distal root), DL - orifice of the distolingual canal (in the RE). e) Follow-up radiograph after six months 

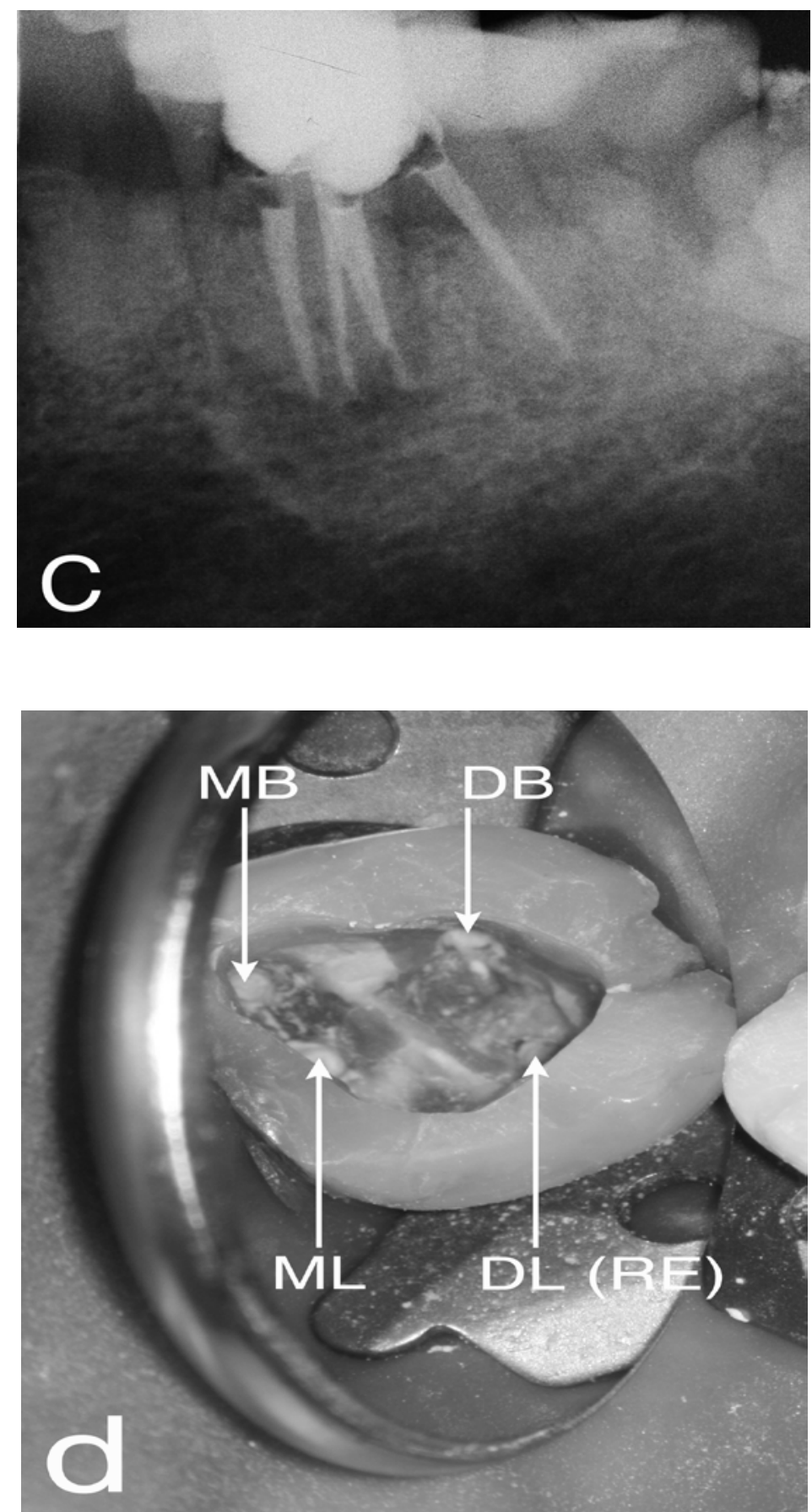

Fig. 2.Klasifikacija izvađenih prvih stalnih mandibularnih(SMPM) sa radiks endomolarisom,prema De Moor et al.33. a) levi SMPM sa tipom I re. b) desni SMPM sa tipa II RE. c) Levi SMPM sa tipom III RE. Svaka slika prikazuje zub sa lingualnogaspekta (levo) i distalnog aspekta (desno). Bela strelica pokazuje nov RE

Fig. 2.Classification of the extracted permanent mandibular first molars (PMFMs) with a radix entomolaris (RE) according to De Moor et al. ${ }^{33}$. a) The left PMFM with a type I RE. b) The right PMFM with a type II RE. c) The left PMFM with a type III RE. Each figure presents the tooth from alingual view (left) and a distal view (right). White arrows indicate the $\mathrm{RE}$ 


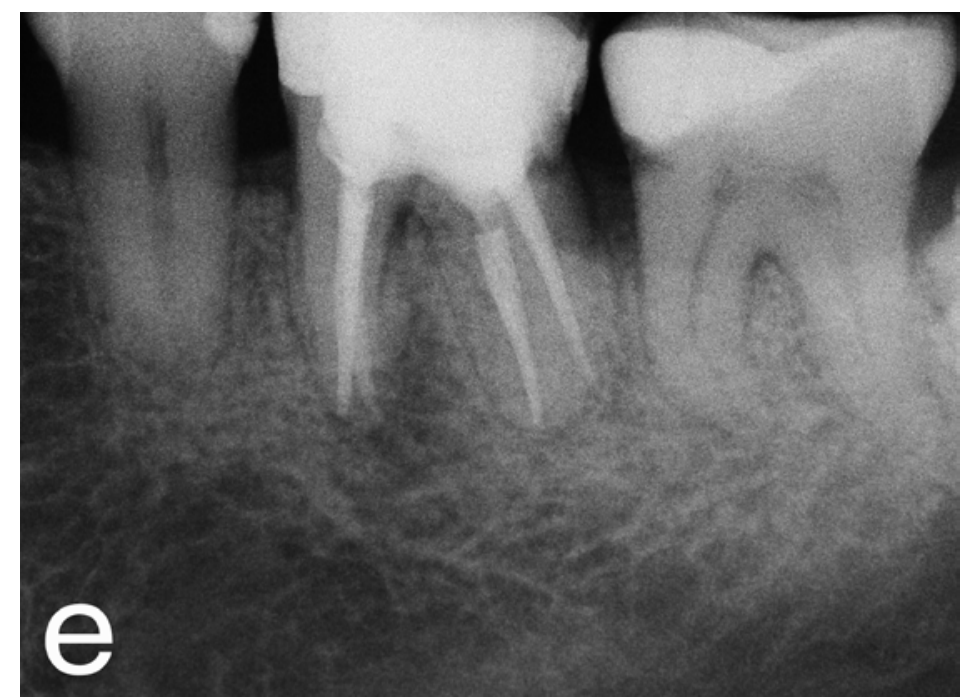

\section{Duskusija}

Morfoloaija korena i korenskog kanala SMPM sa RE

Različite metodologiie korišćene su za analizu morfologije korena i korenskog kanala PMFM sa RE: vizuelni pregled izvađenog zuba $^{5}$, kanalna boienja i kliring korena ${ }^{14,19,22,35,36,}$ konvencionalna radiografija $^{37,38}$, spiralna kompiuterizovana tomografija (SCT ) ${ }^{39}$, konus-zrak kompiuterizovana tomografiia (CBCT $)^{20,21,40}$ i mikrokompiuterizovana tomografija (uCT) ${ }^{6,41,42}$. U tom smislu, važno ie imati na umu da ie većina ovih studija ograničena na zube mongoloidne populaciie, kao što su Kinezi ${ }^{6,21,35,40-42}$ Tajlanđani $^{20,22,38}$ i Koreanci $^{39}$.

U literaturi se često tvrdi da je RE u SMPM kraći od druga dva korena. Međutim, postoje podaci kod malog broj autora. Chen i sar. ${ }^{38}$ pregledali su 21 izvađen zub kod tajvanskih pacijenata i otkrili da je RE bio je značajno kraći kod distalnog korena(p $<0,001$ ), u proseku za $1,48 \mathrm{~mm}$. Gu i sar. ispitali su 20 zuba izvađenih kod kineskih pacijenata i utvrdili da je RE bio u proseku $1,54 \mathrm{~mm}$ kraći od mezijalnog korena $(\mathrm{p}=$ $0,01)$ i $0,88 \mathrm{~mm}$ kraći od distalnog korena (p $<0,001)$.

U ovom slučaju, radna dužina distolingvalnog (RE) kanala bila je kraća nego što je distobukalni kanal za $1 \mathrm{~mm}$.

Nedavno su obiavliena četiri ispitivania vezana za konfiguraciiu korenskog kanala od SMPM sa ili bez RE $\mathrm{E}^{6,19,36,40}$. Konfiguracije korenskog kanala su svrstane

\section{Discussion}

Root and root canal morphology of the $P M F M$ with an $R E$

Different methodologies have been used to analyze the root and root canal morphology of the PMFM with an RE: visual examination of extracted teeth ${ }^{5}$, canal staining and root clearing ${ }^{14,19,22,35,36}$, conventional radiography ${ }^{37,38}$, spiral computed tomography $(\mathrm{SCT})^{39}$, cone-beam computed tomography $(\mathrm{CBCT})^{20,21,40}$, and microcomputed tomography $(\mu \mathrm{CT})^{6,41,42}$. In this regard, it is important to note that the majority of these studies have limited themselves to teeth from Mongoloid populations, such as Chinese ${ }^{6,21,35,40-42}$, Taiwanese ${ }^{20,22,38}$ and Koreans ${ }^{39}$.

In the literature, it is often claimed that the RE of the PMFM is shorter than the other two roots; however, numerical data have been presented only by few authors. Chen et al. ${ }^{38}$ examined 21 teeth extracted from Taiwanese patients and found that the RE was significantly ( $<<0.001$ ) shorter than the distal root, by an average of $1.48 \mathrm{~mm}$. Gu et al. $^{42}$ examined 20 teeth extracted from Chinese patients and found that the RE was on average $1.54 \mathrm{~mm}$ shorter than the mesial root $(\mathrm{p}=0.01)$ and $0.88 \mathrm{~mm}$ shorter than the distal root $(\mathrm{p}<0.001)$. In the presented case, working length of the distolingual (RE) canal was shorter than that of the distobuccal canal by $1 \mathrm{~mm}$. Recently, four studies reported the root canal configuration of the PMFMs with and without an $\mathrm{RE}^{6,19,36,40}$. 
u osam tipova prema Vertučijevim kriterijumima $^{43}$ sa dodatnim modifikacijama. Ove studije su pokazale da RE uvek sadrži jednostavan tip i (jedan kanal) kanalne konfiguraciie, s gotovo okruglim kanalnim poprečnim presekom. Osim toga, nema razlike između obe grupe zuba u konfiguraciji mezijalnog kanala korena. U obe grupe, naičešće konfiguracije mezijalnog kanala korena bile su po tipu IV (dve odvoiene kanalima) (29-94\%) i tipa II (dva kanala koii se pružaiu kraće od vrha) (2-31\%). S druge strane, prisutnost dva kanala (tipa II-VII) registrovana je u distalnom korenovima. Čini se da je ređa u zubima sa RE (5-14\%) nego kod zuba sa dva korena (28-36\%). Kod zuba sa i bez RE i konfiguraciiom postoii konfiguracija $80-99 \%$ i 64-72\% . Osim toga, dvokorene varijante imaju veće varijacije korenskih kanala. Konačno, Gu i sar. ${ }^{6}$ su izvestili da se lateralni kanali i apikalne posledice ređe javliaiu kod zuba sa RE (10\%) nego u mezijalnim (65\%) i distalnim korenovima (40\%). U prikazanom slučaiu, endodontski tretirani SMPM ima četiri kanala, sa dva odvojena kanala (tip IV) mezijalnom korenu, jednim kanalom u RE i jednim u distalnom korenu.

Kanal RE obično je zakrivljen bukolingvalno, ali može takođe biti zakrivljen meziodistalno. Stepen zakrivljenosti korenskog kanala može se izraziti s dva međusobno nezavisna parametra: ugao i radijus zakrivljenosti. Chen i sar. ${ }^{38}$ merili su ugao zakrivljenosti kanala RE na radiogramu 21 izvađenog zuba, koristeći Schneider metod $^{44}$. Prosečni uglovi bili su $36,35^{\circ}$ i $9,24^{\circ}$ za bukolingvalnu i mezioligvalnu zakrivljenost. U 90,5\% kanala RE, bukolingvalni ugao je bio veći od $25^{\circ}$, dok je kod $57,1 \%$ kanala meziodistalni ugao bio manji od $10^{\circ}$. Uporedni rezultati su takođe praćeni od strane Gu i sar ${ }^{41}$. Ovi autori ispitivali su 20 ekstraliralna SMPM sa RE pomoću CBCT. Prosečni uglovi (Schneider metodom) su $32,06^{\circ}$ i $13,81^{\circ}$ za bukolingvalnu i meziodistalnu zakrivljenost. U 95\% kanala RE, bukolingvalni ugao bio je veći od $20^{\circ}$, dok je u $45 \%$ kanala RE meziodistalni ugao bio veci $10^{\circ}$. Maksimalne vrednosti izmerene su $57,00^{\circ}$ i $35,72^{\circ}$ za bukolingvalni i meziodistalni ugao zakrivljenosti. Šta više, kanal RE je imao veći srednji ugao zakrivljenosti od kanala $u$ mezijalnim i distalnim korenovima. De Moor i sar. $^{33}$ su pomenuli slučaj SMPM sa RE u kanalu, koji je skretao bukolingvalno na oko $90^{\circ}$. Gu i sar ${ }^{41}$. su izvestili da je u proseku
The root canal configurations were classified into eight types according to Vertucci's criteria ${ }^{43}$ with additional modifications. These studies have shown that the RE invariably contains a simple type I (single canal) configuration with a nearly round canal cross-section. Moreover, no difference was found between both groups of teeth in canal configuration of the mesial root. In both groups, the most common canal configurations of the mesial root were type IV (two separate canals) (29-94\%) and type II (two canals joining short of the apex) (2-31\%). Conversely, the presence of two canals (types II-VII) in the distal root appears to be less frequent in teeth with an RE $(5-14 \%)$ than in the two-rooted variety (28-36\%). In teeth with and without an RE type I configuration was encountered in $80-99 \%$ and $64-72 \%$ of the distal roots, respectively. In addition, the two-rooted variety possessed a greater variation in canal configuration. Finally, Gu et al. ${ }^{6}$ reported that lateral canals and apical ramifications less frequently occurred in the RE (10\%) than in the mesial $(65 \%)$ and distal roots (40\%). In the presented case, the endodontically treated PMFM was fourcanalled, with two separate canals (type IV) in the mesial root and a single canal in the $\mathrm{RE}$ and the distal root.

The RE canal usually curves buccolingually, but it may also curve mesiodistally. The degree of root canal curvature can be expressed by two mutually independent parameters: the angle and radius of curvature. Chen et al. ${ }^{38}$ measured the angle of RE canal curvature on the radiographs of 21 extracted teeth, using the Schneider method $^{44}$. The average angles were $36.35^{\circ}$ and $9.24^{\circ}$ for buccolingual and mesiodistal curvature, respectively. In $90.5 \%$ of $\mathrm{RE}$ canals, the buccolingual angle was greater than $25^{\circ}$, whereas in $57.1 \%$ of RE canals, the mesiodistal angle was less than $10^{\circ}$. Comparable results were also obtained by $\mathrm{Gu}$ et al. ${ }^{41}$. These authors examined 20 extracted PMFMs with an RE using $\mu \mathrm{CT}$. The average angles (by Schneider method) were $32.06^{\circ}$ and $13.81^{\circ}$ for buccolingual and mesiodistal curvature, respectively. In 95\% of RE canals, the buccolingual angle was greater than $20^{\circ}$, whereas in $45 \%$ of RE canals, the mesiodistal angle was less than $10^{\circ}$. The maximum values measured were $57.00^{\circ}$ and $35.72^{\circ}$ for the buccolingual and mesiodistal angles of curvature, respectively.

Moreover, the RE canal had a greater mean angle of curvature than the canals in 
kanal RE zakrivljen buklingvalno sa većim uglom od kanala sa mezijalnim i distalnim korenom. Osim toga, otkrili su da je prosečni radius zakrivljenosti $\mathrm{RE}$ manji $\mathrm{u}$ bukolingvalnoj od meziodistalne orijentacije $(6,17 \mathrm{~mm}$ u odnosu na 20,99 mm). CBCT slike, prikazane u kliničkom slučaju kod Abellaet i sar. ${ }^{28}$ pokazuju da kanal RE može biti zakrivljen bukolingvalno $\mathrm{s}$ velikim uglom i malim radijusom.

Prema klasifikaciji De Mur i sar. ${ }^{33}$ baziranoj na bukolingvalnoj kurvaturi i lingvalnom nagibu korena, mogu se identifikovati tri tipa RE: tip I predstavlja prav RE koji nije paralelan sa distalnim korenom ( Slika 2a), tip II prav, ali sa lingvalnim nagibom, the mesial and distal roots. De Moor et al. ${ }^{33}$ even mentioned a case of a PMFM in which the RE canal curved buccolingually at about $90^{\circ}$. Gu et al. ${ }^{41}$ also reported that on average the RE canal curves buccolingually with a greater angle than the canals of the mesial and the distal root. In addition, they found that the average radius of the RE canal curvature was smaller in buccolingual than in mesiodistal orientation (6.17 mm vs. 20.99 $\mathrm{mm})$. CBCT images presented in a clinical case of Abellaet al. ${ }^{28}$ show that the RE canal may curve buccolingually with great angle and small radius.
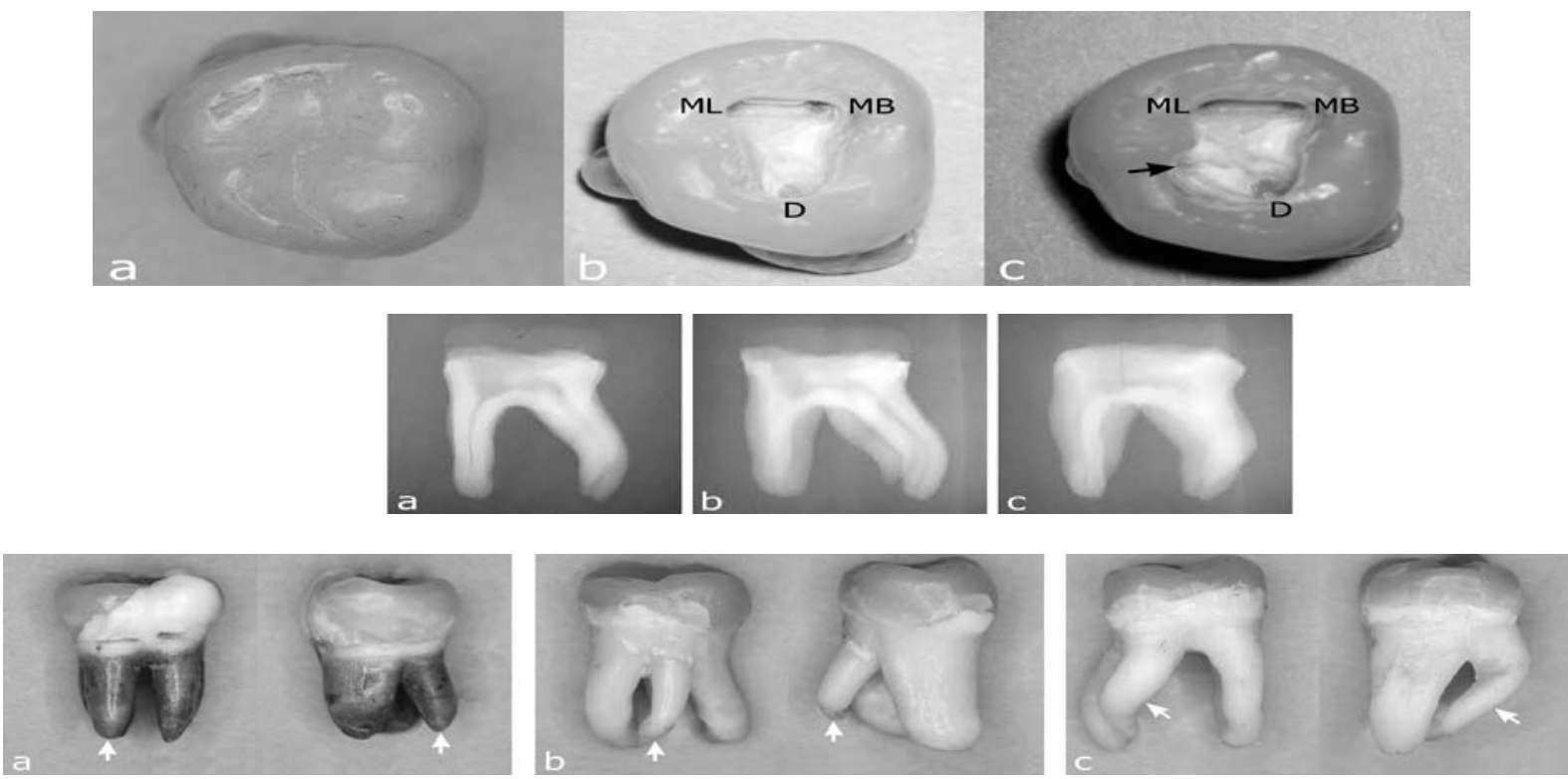

Fig. 3. Radiografije levog mandibularnog prvogmolara sa slika 2c: a) orthoradialna projekcija, b) medijalna ekscentrična projekcija, c) distalna ekscentrična projekcija.On ortoradialnoj projekciji, zub izgleda kao da ima dva korena zbog potpunog preklapanja RE sa distalnim korenom. Mezijalnaprojekcija daje jasnu sliku radiks entomolarisa u odnosu na distalnu ekcentričnu projekciju. Imati u vidu da konvencionalna 2D radiografija prikazuje samo metiodistalnu zakrivljenost korena.

Fig. 3. Radiographic images of the left permanent mandibular first molar from Figure 2c: a) orthoradial projection, b) mesial-excentric projection, c) distal-excentric projection.On orthoradial radiograph, the tooth appears to be two-rooted because of complete overlapping between the radix entomolaris and the distal root. The mesial-excentric projection resulted in a more identifiable radiographic image of the radix entomolaris than the distal-excentric projection. Note that conventional 2D radiographs reveal only root curvatures in the mesiodistal direction

Fig. 4.a) Okluzalni aspekt pravog stalnog mandibularnog molara od Slika 2b pre pripreme pristupnog kvaliteta. b) Standardni tradicionalni pristup kanalnog korena u mezijalnom i distalnom kanalu (ML - otvor meziolingualnog kanala, MB - otvor meziobularnog kanala, D - otvor kanala u distalnom korenu). c) da bi se prikazao otvor radix entomolarisa (strelica), pristupni kavitet je formiran u obliku trapezo. Zapaziti da je dodatni otvor lociran mesiolingvalno u odnosu na otvor kanala distalnog korena

Fig. 4.a) Occlusal view of the right permanent mandibular first molar from Figure $2 b$ before preparation of the access cavity. b) Standard triangular access to the root canals in the mesial and distal roots $(\mathrm{ML}$ - orifice of the mesiolingual canal, $\mathrm{MB}$ - orifice of the mesiobuccal canal, $\mathrm{D}-$ orifice of the canal in the distal root). c) To expose the orifice of the radix entomolaris canal (arrow), the access form was modified to a trapezoidal shape. Note that the additional orifice is located mesiolingually from the orifice of the canal in the distal root 
(Slika 2b), tip III je RE sa lingvalnim nagibom i bukolingvalnom zakrivljenošću (Slika 2c). Merenja na 145 ekstrahiranih mandibularnih stalnih molara, pokazala su da je longitudinalna osa RE I distalnog korena od $0-45^{\circ 5}$.

Song i sar $^{39}$ su proučavali morfološke odlike RE kod Koreanaca, koristeći SCT slike mandibule. Oni su definisali dva dodatna tipa RE: mali tip, kod koga je dužina manja od dužine polovine distalnog kanala, i čak manji konični tip, kod koga se korenski kanal radiografski ne može identifikovati. Kod SMPM tipa II $(47,5 \%)$ i tipa III $(40,5 \%)$, su dominirajući tipovi, zatim tip I $(8,1 \%)$, mali tip $(2,5)$ i konični tip $(1,4 \%)$.

\section{Radiografski izgled SMPM sa RE}

Široko prihvaćeno mišljenje da se RE lako radiološki potvrđuje u oko $90 \%$ slučajeva podržano je studijom od strane Wokera i Quasckenbusha ${ }^{45}$. Ovi autori su određivali broj korenova na radiografijama 100SMPM, uključujući i 25 sa RE. Koristili su nagrizni i panoramski snimak kod kineskih pacijenata, pre vađenja zuba. Određen broj zuba je pogrešno procenjen, samo je dva molara procenjeno da imaju RE (8\%). Kod preostalih 98 molara, radiološki nalaz se slagao sa vizuelnim pregledom ekstrahiranog zuba. Uprkos napred pomenutom, radiografska identifikacija RE može biti izazovni zadatak. Radiografska slika RE, kod SMPM je manje jasna nego slika ostala dva korena, pre svega zbog uzanih dimenzija i preklapanja sa distalnim korenom. Delimično ili kompletno preklapanje može izgledati kao standardno paralelni koren, zbog toga što se RE uglavnom nalazi na bukolingvalnoj površini distanog korena. Osim toga, retko se kad kod pacijenata bele rase očekauje da imaju prekobrojni koren. Zahvaljujući tome, $\mathrm{RE}$ se lako previdi i pogrešno interpretira kao perforacija ili vertikalna fraktura korena na radiografiji i posledično se izostavlja njegovo endodontsko lečenje. Mada RE može biti opisan na panoramskom snimku, ovo je mnogo manje tačan metod nego periapikalna radiografija. $\mathrm{Na}$ panoramskim radiografijama 1353 odraslih Japanaca, SMPM je detektovan u $15,9 \%$ slučajeva, zahvaljujući periapikalnoj radiografiji ${ }^{23}$.

Wang $\mathrm{i}$ sar. ${ }^{47}$ radiografisali su 25 ekstrahiranih SMPM sa RE. Oni su utvrdili statistički značajnu korelaciju među morf -
According to the classification of De Moor et $\mathrm{al}^{33}$, based on the buccolingual curvature and lingual tilting of the root, three types of $\mathrm{RE}$ can be identified. Type I refers to a straight RE, which is parallel to the distal root (Figure 2a), type II to a straight, but lingually tilted RE (Figure 2b), and type III to a lingually tilted and buccoligually curved RE(Figure 2c). Measurements on 145 extracted permanent mandibular molars have shown that the longitudinal axes of the RE and the distal root form an angle from $0^{\circ}$ to about $45^{\circ}$.

Song et al. ${ }^{39}$ studied the morphological features of RE in Korean individuals using SCT images of the mandibles. They defined two additional types of RE: a small type, in which the length is shorter than half the length of the distal root, and even a smaller conical type, in which the root canal is radiographically unidentifiable. In PMFMs, types II (47.5\%) and III (40.5\%) were the prevalent types, followed by type I $(8.1 \%)$, small type (2.5\%), and conical type (1.4\%).

\section{Radiographic appearance of the PMFM with an $R E$}

The widely accepted view that the $\mathrm{RE}$ is readily evident radiographically in about $90 \%$ of cases has been supported by a study of Walker and Quackenbush ${ }^{45}$. These authors determined the number of roots on radiographs of 100 PMFMs, including 25 teeth with an RE. They used bitewing and panoramic radiographs made in Chinese patients before the teeth were extracted. The number of roots was incorrectly determined only in two molars with an RE (8.0\%). In the remaining 98 molars, the results of the radiographic examination were in agreement with those of the visual examination of the extracted tooth.

Despite the aforementioned, the radiographic identification of an RE may be a challenging task. The radiographic image of an RE in the PMFM is less clear than that of the other two roots, which is due to its slender dimensions and overlappingwith the distal root. Partial or complete overlapping can appear on standard parallel views because the RE is mostly situated in the same buccolingual plane as the distal root. In addition, the PMFM in a Caucasian patient is usually not suspected of having a super- 
ološkiom tipovima RE po De Mooru i sar. ${ }^{33}$ kao i slaganje u preklapanju na ortoradijanim radiografijama. U svim tipovima,RE je bio potpuno preklopljen sa distalnim korenom, u tipu II najčešće je stizao $(55,6 \%)$ do polovine distalnog korena, kod tipa III (50\%) RE je dosezao do cervikalne trećine korena. Drugim rečima, tip i Re je najteže radiografski identifikovati. i ako nije procenjeno u prethodno pomenutoj studiji , RE malog i koničnog tipa, su verovatno najteži za identifikaciju konvencionalnom radiografijom. U gore navedenoj SCT studiji kod Koreanaca, 12\% RE mogu se podvesti pod RE tip i, mali i konični tip. Ovo je otprilike u skladu sa $8 \%$ ortoradiogrfski nedostajućim RE, koji su prijavili Woker i Quasckenbush $^{45}$.

U poslednje vreme najbitniji cilj detekcije RE je precizna radiografska studija. Radiografiju bi trebalo postaviti u kutiju za gledanje i po potrebi koristiti uveličavajuće sočivo. Svetlo koje okružuje radiograski snimak bi trebalo blokirati jednostavnim uređajem, recimo parčetom kartona ukrojenim oko snimka. Uvek kada je obris distalnog korena nejasan, kada se duplira ili se pojavljuje na bilo koji drugi način od očekivanog, trebalo bi posumnjati na prisustvo RE, sve dok dodatna radiografska snimanja ili endodontska eksploracija ne isključe ovu mogućnost. Preklapanje radiografskih linija koje definišu pulpu ili periodontalni ligament mogu biti nagoveštaj $\mathrm{RE}^{45}$. U ovom slučaju, pažljivom inspekcijom preoperativne radiografije ustanovljene su duple linije distalnog kanala, sugerišući na prisustvo RE.

Radiografija iz drugog ugla je obično neophodna da bi se potvrdilo prisustvo RE. Po principu paralakse, ILSB (istovetnolingvalno, suprotno-bukalno) pravilu lingvalno pozicioniran koren $\mathrm{RE}$, delije kao da se kreće u pravcu istom sa pravcem centralnog zraka, dok se bukalno pozicioniran koren (distalni koren) kreće u pravcu suprotnom od centralnog zraka (Slika3, a-c) . Ukuliko se upotrebi mezijalnoekscentrična projekcija, RE će izgledati kao da se udaljava mezijalno, i može se uspešno razgraničiti od distalnog korena sa kojim se preklapa ( Slika 1b-1c, 3a i 3b). U kurziv studiji koju su izveli Wang i sar. $^{47}$ dokumentovane su radiografske odlike 25 ekstrahiraranih SMPM-a sa RE-om sa različitom projekcijom centralnog zraka $\mathrm{u}$ horizontalnoj ravni. Oni su utvrdili da je mezijalna radiografija pod uglom od radiografija $25^{0}$ značajno bolja od radiografije numerary root. Because of these facts, the $\mathrm{RE}$ is most easily overlooked or wrongly interpreted (as a perforation or a vertical root fracture) on the radiograph and consequently missed during endodontic treatment. Although the RE can be depicted in a panoramic radiograph, this is a considerably less accurate method than periapical radiography. In panoramic radiographs of 1353 Japanese adults, PMFMs with an RE were detected in only $15.9 \%$ of cases found with periapical films ${ }^{23}$.

Wang et al. $^{47}$ radiographed 25 extracted PMFMs with an RE. They found a statistically significant correlation between the morphological types of RE as defined by De Mooret al. ${ }^{33}$ and the degree of overlapping on orthoradially exposed radiographs. In all type i cases, RE completely overlapped with the distal root, in type II REs it was most frequently (55.6\%) limited to the distal half of the root, and in type III REs it was most frequently $(50.0 \%)$ limited only to the cervical part of the root. In other words, type I REs presented the least identifiable radiographic images. Although not evaluated in the aforementioned study, REs of the small and conical types are most probably also difficult to identify on conventional radiographs. The above-mentioned SCT study of the PMFMs in Koreans has shown that $12.0 \%$ of REs could be classified as type I, the small and conical types ${ }^{39}$. This is roughly consistent with $8.0 \%$ of radiographically missed REs reported by Walker and Quackenbush ${ }^{45}$. Currently, the most important aid in detecting an RE is a careful study of the radiograph.

The radiograph should be placed on a viewing box and, if necessary, evaluated using a magnifying lens. The light surrounding the radiograph can be blocked by a simple device, e.g. a piece of a cardboard with a cutout for the radiograph. Whenever the outline of the distal root is unclear, double, or differs in any way from the expected radiographic appearance, one should suspect the presence of an RE until additional radiographs and endodontic exploration exclude its presence.The crossing of radiolucent lines defining the pulp space and periodontal ligamentis considered to be a tell-tale feature of an $\mathrm{RE}^{45}$. In the presented case, a careful inspection of the preoperative radiograph revealed double outline of the distal root, suggesting the presence of an RE.A subsequent tangled radiograph is usually necessary to confirm the presence of the RE. 
pod distalnim uglom od $25^{\circ}$ za procenu prisustva RE. Oni su takođe otkrili da distalna horizontalna angolacija nema mnogo uticaja na dijagnozu RE, naročito kada je distalna angulacija mala.

$\mathrm{Za}$ određivanje morfologije $\mathrm{RE}$, neophodna je trodimenzionalna radiografija. Vredno je pomenuti dve kliničke morfološke odlike RE (lingvalni nagib i bukolingvalnu zakrivljenost) Slika 2c, koje se ne mogu registrovati konvencionalnom radiografijom (Slika 3a-c). Kombim kompijuterizovana tomografija (CBCT) u novije vreme uveden metod snimanja prevazilazi ova ograničenja i dozvoljava vizuelizaciju korenskog kanala u sve tri dimenzije. U ovom slučaju CBCT je bio od neprocenjiv za endodontski tretman SMPM sa vrlo zakrivljenim kanalom $\mathrm{RE}^{28}$.

Dizajn pristupnog kaviteta i instrumentacija kanala korena SMPM sa RE-om.

Mnogi klinički zaključci se mogu izvesti morfologije korena i kanala korena zuba sa RE-om. Na podu pulpne komore, otvor kanala RE,a je lokalizovan distomezio-lingvalno od otvora kanala distalnog korena $^{34}$. Zbog toga, dizajn pristupnog kaviteta odgovara molaru sa dva korena, ostavljajući otvor RE neistraženim (Slike 4a i 4b). Ekstenzija distolingvalnog ugla pristupnog kaviteta u lingvalnom pravcu je neophodna, da bi obezbedila direktan pristup kanalu RE-a (Slika4c). Ova modifikacija rezultira trapezastim oblikom pristupnog kaviteta. Uglovi trapezoida bi trebalo da odgovaraju mestu otvora.

Prema zakonima simetrije, koji su postavili Krasner i Rankov ${ }^{48}$,otvori kanala na istom korenu su jednako udaljeni od zamišeljene meziodistaln linije kroz centar poda pulpne komore i leži na liniji normale na nju. U slučaju RE, po pravilu se primenjuje na oba mezijalna otvora (Slika 4c). Zbog toga, ekscentrična pozicija distolongvalnog otvora, dozvoliće lekaru da pristupi otvoru kanala korena RE (Slika 1d). Poznavanje unutrašnjeg promera otvora kanala, može biti od koristi za lociranje kanala RE. Ovi podaci nalaze su i kurziv CBST studiji na 63 zuba $^{20}$ na studiji, 20 ekstrahiranih zuba ${ }^{6}$. U prvoj studiji otvor kanala kod RE bio je u proseku 2,7 mm udaljen od distalnog otvora i 3,5 mm udaljen od meziolingvalnog otvora.
According to the principle of parallax or the SLOB (Same Lingual, Opposite Buccal) rule, the lingually positioned root (RE) appears to move in the direction of the central ray deviation, while the buccally positioned root (distal root) appears to move in the opposite direction (Figures 3a-c). If a mesial-excentric projection is employed, the RE will appear to wander mesially, and can also be successfully removed from any overlapping by the distal root (Figures $1 \mathrm{~b}$ and $1 \mathrm{c}, 3 \mathrm{a}$ and $3 \mathrm{~b})$. An in vitro study by Wang et al. ${ }^{47}$ documented the radiographic features of 25 extracted PMFMs with an RE at various central ray projections in a horizontal plane. They found that $25^{\circ}$ mesial radiographs were significantly better than $25^{\circ}$ distal radiographs for assessing the presence of an RE. They also found that distal horizontal angulation had little effect on diagnosing the RE, particularly when a radiograph was taken from a small angle distally.

For the determination of $\mathrm{RE}$ morphology, radiographic examination in the third dimension is indispensable. Worthy of note is that the two clinically relevant morphological features of an RE (lingual tilting and buccolingual curvature) (Figure 2c) cannot be visualized by conventional radiography (Figures 3a-c). Cone-beam computed tomography (CBCT), a recently introduced imaging method, overcomes these limitations allowing the visualization of root morphology in all three dimensions. A CBCT scan also reveals the canal system inside each root and allows angulation and distance measurements. In a recent case report, CBCT was recognized as an invaluable diagnostic tool in endodontic treatment of the PMFM with a severely curved $\mathrm{RE}^{28}$.

Access cavity design and root canal instrumentation in the PMFM with an RE

Numerous clinical inferences can be drawn from root and root canal morphology of PMFMs with an RE. In the pulp chamber floor, the orifice of the RE canal is located disto- to mesio-lingually from the orifice(s) of the canal(s) in the distal root ${ }^{34}$. Therefore, the access cavity design, which is appropriate for two-rooted molars, leaves the RE orifice unexposed (Figures 4a and 4b). Extension of the distolingual corner of the 
U drugoj studiji, ulaz u kanal korena RE bio je u proseku 2,9 mm udaljen od ulaza u oba susedna kanala korena. Konačno, tamne razvojne linije na podu pulpne komore, kao i bojenje metilen plavim, daju indiciju za precizno lociranje otvora kanala RE. U ovom pogledu, upotreba mikroskopa i uveličavajućih tehnika može biti od koristi.

Kanal korena RE, sa svojim jednostavnim tubularnim oblikom, i skoro okruglog poprečnog preseka, sa odsustvom lateralnih kanala i apikalnih ramifikacija, može biti zadovoljavajuće očišćen i samo mehaničkom preparacijom. U ovom slučaju, treba obratiti pažnju na gracilnost zidova korenskog kanala kako bi se izbegla perforacija i slabljenje korena. Gu i sar $^{4}$. prijavili su da je najosetljivije područije u predelu srednje trećine korena $4 \mathrm{~mm}$ od apikalnog foramena, gde je debljina korenskog zida oko $1,15 \mathrm{~mm}$. Zbog toga treba izbegavati ekscesivni koronarni pristup i uklanjanje radikularnog dentina tokom instrumentacije kanala korena RE. U skladu sa varijabilnom morfologijom relativno tankih dentalnih zidova i njihovom zakrivljenošću, RE nije pogodan kao nosač protetskih nadoknada.

Dodatni izazov za endodontski tretman, je bukolingvalna zakrivljenost tipa III RE (prema klasifikaciji De Mur i sar ${ }^{33}$. zato što raste rizik od aberacija oblika kao što su zaravnjenost ili suženje kanala. Zakrivnjenost korenskog kanala malog radijusa je delimično teško obraditi. Mali instrumenti od nerđajućeg čelika ubačeni u kanal korena mogu se upotrebiti i za dobijanje informacija o njegovoj morfologiji.

Kada se ovi instrumenti povuku iz korenskog kanala, njihov oblik postaje replikacija trodimenzionalne zakrivljenosti kanala korena ${ }^{49}$. Prikazani slučaj predstavlja tip III RE, zbog zakrivljenosti bukolingvalnog kanala koja je utvrđena klinički. Dentinska pregrada, često prisutna na ulazu u kanal korena RE, povećava ugao zakrivljenosti korenskog kanala na isti način kao i meziodentalne pregrade ${ }^{6}$. Ove dentinske pregrade moraju se ukloniti Gejts- Gliden svrdlima, titanijum-niklovanim rotirajućim instrumentom sa širokim konusom, ili ultrasoničnim instrumentom, tako eliminišući vrtnu krivinu korenskog kanala. Drugim rečima, treba doterati koronarno proširenje relokacjom otvora $\mathrm{RE} u$ lingvalnom pravcu kako bi se postigao pravolinijski pristup. access cavity in alingual direction is necessary to provide direct access to the RE canal (Figure 4c). This modification results in a trapezoid-shapedaccess cavity outline. The corners of the trapezoid should correspond to the positions of the orifices.

According to the laws of symmetry, postulated by Krasner and Rankow ${ }^{48}$, the orifices of the canals in the same root are equidistant from an imaginary mesio-distal line across the center of the pulp chamber floor and lie on a line perpendicular to it. In the case of an RE, these laws apply only to both mesial orifices (Figure 4c). Therefore, eccentric position of the distolingual orifice should alert the practitioner to the possibility of an RE canal orifice (Figure 1d). The knowledge of the average interorifice distances can also be useful for locating the $\mathrm{RE}$ canal. These data come from in vivo CBCT study of 63 teeth $^{20}$ and from a $\mu \mathrm{CT}$ study of 20 extracted teeth ${ }^{6}$. In the first study, the RE orifice was on average $2.7 \mathrm{~mm}$ away from the distal orifice and $3.5 \mathrm{~mm}$ away from the mesiolingual orifice. In the second study, the RE orifice was on average $2.9 \mathrm{~mm}$ away from both adjacent orifices. Finally, dark developmental lines on the pulp chamber floor as well as staining with methylene blue dye may provide clues to the precise location of the RE orifice. In this respect, the use of microscopy and other magnification techniques can be helpful.

The RE canal with its simple tubular shape, a nearly round cross-section, and absence of lateral canals and apical ramifications may be cleaned satisfactorily by mechanical preparation alone. In this respect, thickness of the radicular wall should be considered during root canal instrumentation to avoid perforation or weakening of the root. Gu et al.42 reported that the most endangered area was located at the middle level of the RE canal, $4 \mathrm{~mm}$ from the apical foramen, where the thickness of the mesial wall averaged only $1.15 \mathrm{~mm}$. Therefore, excessive coronal enlargement or removal of the radicular dentine should be avoided during RE canal instrumentation. Moreover, due to the highly variable morphology, relatively thin dentinal walls, and curvature, an RE is not suitable for anchoring prosthetic dowels.

The additional challenge of endodontic treatment is abuccolingual curvature of the type III RE (according to the classification of De Moor et al. ${ }^{33}$ ), because it increases the 
Upotreba nikl-titanijum rotirajućih instrumenata za oblikovanje kanala RE bila je navedena od strane više autora ${ }^{28,34}$. Prednost ovi instrumenata nad instrumentima od nerđajućeg čelika je bolja prilagodljivost kanalnoj geometriji, i mogućnost dostizanja originalnog oblika kanala, čak i kod veoma zakrivljenih kanala ${ }^{50}$. Na žalost, rizik od lomljenja instrumenata raste sa pojačanjem krivine kanala korena. Rotacija instrumenta u zakrivljenom kanalu uzrokuje zamor metala i posle određenog broja rotacionih ciklusa, instrument se lomi. Jača krivina korena (veći ugao ili smanjeni radijus krivine), ubrzava zamor metala i povećava rizik od loma instrumenta ${ }^{51,52}$. Mogućnost lomljenja instrumenta u zakrivljenom kanalu raste sa dijametrom instrumenta, u najzakrivljenijem delu kanala, koja je određena tipom veličine i konusom instrumenta ${ }^{53}$. Drugi faktor koji bi trebalo uzeti u razmatranje je lokacija krivine, s obzirom da dijametar instrumenta opada prema tipu. Gu i $\operatorname{sar}^{41}$.su konstatovali da se krivina može prostirati kroz manji ili veći deo kanala RE, dovodeći do lomljenja instrumenta na bilo kom nivou korenskog kanala. Kako bilo, oni su takođe našli da je kanal RE skoro okrugao i da je vrh njegovog konusa oko 0,03 u srednjoj i apikalnoj trećini u bukolingvalnom i meziodistalnom pravcu. Zbog toga, turpije sa malim konusom (na pr.0,04) će dozvoliti adekvatnu preparaciju kanala korena RE, sa smanjenim rizikom od lomnjenja fleksibilnih instrumenata $^{54}$. Dalje, doterivanje koronarnog pristupa, sa relokacijom otvora kanala RE u lingvalnom pravcu, kroun daun tehnika instrumentacije i održavanje ravne pristupne putanje koristeći ručne instrumente će takođe smanjiti rizik od proceduralnih greški.

Potrebe za endodontskom obradom trokorenskog SMPM smatra se profesionalnim izazovom. Američka asocijacija za endodonciju (AAE) i Kanadska Akademija za endodonciju (CAE), dizajnirala je težinu slučajeva kako bi lekara dovela do prave odluke u načinu lečenja ${ }^{55,56}$. Prema ovom vodiču, jako zakrivljen kanal korena više od $30^{0}$ se klasifikuje u slučajeve velike težine i zbog povećanog rizika od zadržavanja ili lomljenja instrumenta u kanalu. Zbog toga prisustvo RTE može biti osnova za konsultaciju specijaliste, zavisno od stepena veštine koju ima stomatolog opšte prakse. risk of shaping aberrations such as straightening andledging of the root canal.Root canal curvatures with small radii are particularly difficult to prepare. Small stainless-steel instruments inserted into the root canal can be used to gather information about its morphology. As these instruments are withdrawn from the root canal, their shape replicates the three-dimensional curvature of the canal ${ }^{49}$. The presented case was classified as type III RE, because buccolingual canal curvature was established clinically. An overhanging dentine shelf, often present above the orifice of the RE canal increases the angle of the root canal curvature in a similar way as mesial dentine shelves ${ }^{6}$. The dentine shelf must be removed using Gates-Glidden drills, nickel-titanium rotary files with a large cone, or ultrasonically powered instruments, thereby eliminating the cervical curve of the root canal. In other words, coronal preenlargement with relocation of the RE orifice in a lingual direction is indicated to achieve a straight-line access.

The use of nickel-titanium rotary instruments for shaping of the RE canal has been advocated by several authors ${ }^{28,34}$. The advantage of these instruments compared with stainless steel manual instruments is that they achieve better canal geometry and are able to maintain original canal curvature even in severely curved canals ${ }^{50}$. Unfortunately, canal curvature increases the risk of instrument fracture. Rotation of the instrument in a curved root canal causes metal fatigue and after a specific number of rotary cycles the instrument breaks. A pronounced canal curvature (great angle or small radius of curvature) accelerates fatigue and increases the risk of instrument breakage ${ }^{51,52}$. In addition, the possibility of instrument fracture in a curved canal increases with the diameter of the instrument in the most curved portion of the canal, which is determined by tip size and taper of the instrument ${ }^{53}$. Another factor that should be taken into consideration is the location of the curvature since the diameter of the instrument decreases towards the tip. $\mathrm{Gu}$ et al. ${ }^{41}$ have asserted that the curvature might distribute over a large or entire portion of the RE canal, implying that the instrument fracture can occur at any level during root ca nal preparation. However, they have also found that the RE canal is nearly round and that its average taper is close to 0.03 for the middle and apical thirds in buccolingual and mesiodistal directions. Therefore, files with a 


\section{Zaključak}

Sa kliničke tačke gledišta, prevalencija SMPM sa prisustvom RE kod pacijenata bele rase nije neznatna i kreće se $u$ proseku oko $0,7 \%$. do 3,4\% zavisno od studije na ekstrahiranim zubima ili radiografijama. Preovladava mišljenje u literaturi da je u većem broju slučajeva RE identifikovan pažljivom periapikalnom radiografijom. Ipak, manje je jasna radiografska slika RE nego ostala dva korena zbog njegove manje dimenzije i superpozicije (preklapanja) sa distalnim korenom. Zbog toga je neophodna predostrožnost u čitanju radiografije, u slučaju sumnje treba napraviti radiografiju pod mezijalnim uglom, koja bi omogućila odvajanje RE od distalnog korena i njegovu jasnu radiografsku sliku. RE je često jako zakrivljen bukolingvalno. Ovo nije očigledno na radiografskim snimcima, ali se uočava na CBCT, ili se može klinički dijagnostikovati upotrebom turpija K-tipa. Otvor kanala se nalazi na dnu pulpne komore i orijentisan je bukolingvalno od korenskog kanala distalnog korena. Zbog toga, distolingvalni ugao pristupnog kaviteta mora biti proširen lingvalno, da bi dozvolio pravolinijski pristup kanalu RE. Lingvalna inklinacija, bukolingvalna zakrivljenost i relativno tanki zidovi RE, dovode do komplikacija u instrumentaciji kanala korena RE. Zahvaljujući njegovom okruglom obliku i malom prirodnom konusu, RE može biti adekvatno obrađen korišćenjem turpija sa konusom 0,04 . small taper (e.g. 0.04) will allow adequate preparation of the RE canal with a reduced risk of flexion-caused instrument failure ${ }^{54}$.

Furthermore, coronal pre-enlargement with relocation of the RE orifice in a lingual direction, crown-down instrumentation technique, and maintenance of a patent glide path using hand instruments will also minimize the risk of procedural errors.

The three-rooted PMFM in need of endodontic treatment is a considerable professional challenge. The American Association of Endodontists (AAE) and the Canadian Academy of Endodontics (CAE) designed case difficulty assessment guidelines to aid the practitioner with referral decision making ${ }^{55,56}$. According to these guidelines, a severe root canal curvature $\left(>30^{\circ}\right)$ is sufficient to classify a case as highly difficult, as there is an increased risk of creating a blockage or fracturing an instrument in the canal. Therefore, the presence of an RE may be the basis for consultation with a specialist, depending on the practitioner's level of competence in endodontics.

\section{Conclusion}

From a clinical viewpoint, the prevalence of the permanent mandibular first molar (PMFM) with a radix entomolaris (RE) in Caucasian populations is not negligible and ranges from $0.7 \%$ to $3.4 \%$ according to studies conducted on extracted teeth and radiographs.The prevailing opinion in the literature is that in the great majority of cases, the RE can be identified by careful examination of the periapical radiograph. However, the radiographic image of an RE is less clear than that of the other two roots because of its slender dimensions and superimposition (overlapping) with the distal root. Therefore, vigilance is necessary in interpreting radiographs; if in doubt, a second radiograph should be taken at a mesial angle to allow separation of the RE and the distal root in the processed image. The RE is often severely curved buccolingually. This is not obvious on radiographs, but can be visualized on CBCT images or determined clinically by exploration of the RE canal with small Ktype files. The orifice of the root canal is located in the floor of the pulp chamber 
disto- to mesio-lingually from the orifice(s) of the root canal(s) in the distal root. Therefore, the distolingual corner of the access cavity must be extended lingually to allow straight-line access to the RE canal. Lingual inclination, buccolingual curvature, and relatively thin walls of the RE introduce complexity into the root canal instrumentation procedure. Due to its round shape and small natural taper, the RE canal can be adequately prepared using the instruments with taper 0.04 .

\section{LITERATURA /REFERENCES}

1 Vertucci FJ, Haddix JE, Britto LR. Tooth morphology and access cavity preparation. In: Cohen S, Hargreaves KM, eds. Pathways of the pulp. 9th ed. St. Louis: Mosby; 2006:148-232.

2. De Pablo OV, Estevez R, Sanchez MP, Heilborn C, Cohenca N. Root anatomy and canal configuration of the permanent mandibular first molar: a systematic review. J Endod2010;36:1919-31.

3.Visser JB.BeitragzurKenntnis der menschlichenZahnwurzelformen. Zürich: Rotting; 1948.

4. Winkler MP, Ahmad R. Multirooted anomalies in the primary dentition of Native Americans. J Am Dent Assoc 1997;128:1009-11.

5. Carlsen O, Alexandersen V. Radix entomolaris: identification and morphology. Scand J Dent Res 1990;98:363-73.

6. Gu Y, Lu Q, Wang H, Ding Y, Wang P, Ni L. Root canal morphology of permanent three-rooted mandibular first molars: part I - pulp floor and root canal system. J Endod 2010;36:990-4.

7. Huang RY, Lin CD, Lee MS, et al. Mandibular disto-lingual root: a consideration in periodontal therapy. J Periodontol 2007;78:1485-90.

8. Bolk L. BemerkungenüberWurzelvariationen am menschlichenunterenMolaren. Z MorpholAnthropol 1915;17:605-10.

9. Hjelmman G. MorphologischeBeobachtungenan den Zähnen der Finnen. Acta Society of Medicine FennDuodecim 1929;11:1-136.

10. Curzon MEJ. Three-rooted mandibular permanent molars in English Caucasians. J Dent Res 1973;52:181.
11. Schäfer E, Breuer D, Janzen S. The prevalence of three-rooted mandibular permanent first molars in a German population. J Endod 2009;35:202-5.

12. Ferraz JAB, Pécora JD. Three-rooted mandibular molars in patients of Mongolian, Caucasian and Negro origin.Braz Dent J 1993;3:113-7.

13. Sperber GH, Moreau JL. Study of the number of roots and canals in Senegalese first permanent mandibular molars.IntEndod J 1998;31:117-22.

14. Ahmed HA, Abu-bakr NH, Yahia NA, Ibrahim YE. Root and canal morphology of permanent mandibular molars in a Sudanese population.IntEndod J 2007;40:766-71.

15. Garg AK, Tewari RK, Kumar A, Hashmi SH, Agrawal N, Mishra SK. Prevalence of three-rooted mandibular permanent first molars among the Indian population. J Endod 2010;36:1302-6.

16. Chandra SS, Chandra S, Shankar P, Indira R. Prevalence of radix entomolaris in mandibular permanent first molars: a study in a South Indian population. Oral Surg Oral Med Oral Pathol Oral RadiolEndod 2011;112: e77-e82.

17. Turner CG. Three-rooted mandibular first permanent molars and the question of American Indian origins. Am J Phys Anthropol 1971;34:229-41.

18. Reichart PA, Metah D. Three-rooted permanent mandibular first molars in the Tai. Community Dent Oral Epidemiol 1981;9:191-2.

19. Gulabivala K, Opasanon A, Ng YL, Alavi A. Root canal morphology of Thai mandibular molars. IntEndod J 2002;35:56-62. 
20. Tu MG, Huang HL, Hsue SS, Hsu JT, Chen SY, Jou MJ, et al. Detection of permanent three-rooted mandibular first molars by cone-beam computed tomography imaging in Taiwanese individuals. J Endod 2009;35:503-7.

21. Zhang $\mathrm{R}$, Wang $\mathrm{H}$, Tian $\mathrm{YY}, \mathrm{Yu} \mathrm{X}, \mathrm{Hu} \mathrm{T}$, Dummer PMH. Use of cone-beam computed tomography to evaluate root and canal morphology of mandibular molars in Chinese individuals. IntEndod J 2011;44:990-9.

22. Chen G, Yao H, Tong C. Investigation of the root canal configuration of mandibular first molars in a Taiwan Chinese population. IntEndod J 2009;42:1044-9.

23. Harada Y, Tomino S, Ogawa K, Wada T, Mori S, Kobayashi $S$ et al. Frequency of three-rooted mandibular first molars. Survey by x-ray photographs.Shika Kiso IgakkaiZasshi 1989;31:13-18.

24. Curzon ME. Miscegenation and the prevalence of three-rooted mandibular first molars in the Baffin Eskimo. Community Dent Oral Epidemiol 1974;2:130-1.

25. Yang Y, Zhang LD, Ge JP, Zhu YQ. Prevalence of 3-rooted first permanent molars among a Shanghai Chinese population. Oral Surg Oral Med Oral Pathol Oral RadiolEndod 2010;110:e98e101.

26. Midtbø M, Halse A. Root length, crown height, and root morphology in Turner syndrome. ActaOdontolScand 1994;52:303-14.

27. Segura-Egea JJ, Jiménez-Pinzón A, Ríos-Santos JV. Endodontic therapy in a three-rooted mandibular first molar: importance of a thorough radiographic examination. J Can Dent Assoc 2002;68:541-4.

28. Abella F, Mercadé M, Duran-Sindreu F, Roig M. Managing severe curvature of radix entomolaris: three-dimensional analysis with cone-beam computed tomography. IntEndod J 2011;44:87685.

29. Bonaccorso A, Tripi TR. Root canal treatment of a three-rooted mandibular first molar: a case report. ENDO (LondEngl) 2008;2:211-7.

30. Schumacher C. Endodontic treatment of a mandibular first molar with radix entomolaris: a case report. ENDO (LondEngl)2008;2:301-4.

31.Štamfelj I. Endodontsko zdravlje-njeprvegaspo dnjegastalnegakočnika $\mathrm{z}$ nadštevilnokoreninoradix entomolaris. ZobozdravVestn2012;67:74-83.

32. Law AS, Beaumont RH. Resolution of furcation bone loss associated with vital pulp tissue after nonsurgical root canal treatment of three-rooted mandibular molars: a case report of identical twins. J Endod 2004;30:444-7.

33. De Moor RJG, Deroose CAJG, Calberson FLG. The radix entomolaris in mandibular first molars: an endodontic challenge. IntEndod J 2004;37:78999.

34. Calberson FL, De Moor RJ, Deroose CA. The radix entomolaris and paramolaris: clinical approach in endodontics. J Endod 2007;33:58-63.

35. Walker RT. Root form and canal anatomy of mandibular first molars in a southern Chinese population. Endod Dent Traumatol 1988;4:19-22.

36. Gulabivala K, Aung TH, Alavi A, Ng YL. Root and canal morphology of Burmese mandibular molars.IntEndod J 2001;34:359-70.

37. Younes SA, Al-Shammery AR, El-Angbawi MF. Three-rooted permanent mandibular first molars of Asian and black groups in the Middle East. Oral Surg Oral Med Oral Pathol 1990;69:102-5.

38. Chen YC, Lee YY, Pai SF, Yang SF. The morphologic characteristics of the distolingual roots of mandibular first molars in a Taiwanese population. J Endod2009;35:643-5.

39. Song JS, Choi HJ, Jung IY, Jung HS, Kim SO. The prevalence and morphologic classification of distolingual roots in the mandibular molars in a Korean population. J Endod 2010;36:653-7.

40. Wang Y, Zheng QH, Zhou XD, et al. Evaluation of the root and canal morphology of mandibular first permanent molars in a Western Chinese population by cone-beam computed tomography. J Endod 2010;36:1786-9.

41. Gu Y, Lu Q, Wang P, Ni L. Root canal morphology of permanent three-rooted mandibular first molars: part II - measurement of root canal curvatures. J Endod 2010;36:1341-6.

42. Gu Y, Zhou P, Ding Y, Wang P, Ni L. Root canal morphology of permanent three-rooted mandibular first molars: part III - an odontometric analysis. J Endod 2011;37:485-90.

43. Vertucci FJ. Root canal anatomy of the human permanent teeth. Oral Surg Oral Med Oral Pathol 1984;58:589-99.

44. Schneider SW. A comparison of canal preparations in straight and curved root canals. Oral Surg Oral Med Oral Pathol 1971;32:271-5.

45. Walker RT, Quackenbush LE. Three-rooted lower first permanent molars in Hong Kong Chinese. $\mathrm{Br}$ Dent J 1985; 159: 298-9.

46. Tu MG, Tsai CC, Jou MJ, Chen WL, Ghang YF, Chen SY, et al. Prevalence of three-rooted mandibular first molars among Taiwanese individuals. J Endod 2007;33:1163-6.

47. Wang Q, Yu G, Zhou XD, Peters OA, Zheng QH, Huang DM. Evaluation of X-ray projection angulation for successful radix entomolaris diagnosis in mandibular first molars in vitro. $\mathrm{J}$ Endod 2011;37:1063-8.

48. Krasner P, Rankow HJ. Anatomy of the pulpchamber floor. J Endod 2004;30:5-16.

49.Jerome CE, Hanlon RJ. Identifying multiplanar root canal curvatures using stainless-steel instruments. J Endod 2003;29:356-8.

50.Peters OA. Current challenges and concepts in the preparation of root canal systems. J Endod 2004;30:559-67.

51. Zelada G, Varela P, Martin B, Bahillo JG, Magan F, Ahn S. The effect of rotational speed and the curvature of root canals on the breakage of rotary endodontic instruments. J Endod 2002;28:540-2.

52. Martin B, Zelada G, Varela P, Bahillo JG, Magan F, Ahn S, Rodriguez C. Factors influencing the 
fracture of nickel-titanium rotary instruments. 55.Case difficulty assessment form and IntEndod J 2003;36:262-6.

53. Plotino G, Grande NM, Melo MC, Bahia MG, Testarelli L, Gambarini G. Cyclic fatigue of NiTi rotary instruments in a simulated apical abrupt curvature. IntEndod J2010;43:226-30.

54.Abella F, Patel S, Duran-Sindreu F, Mercade M, Roig M. Mandibular first molars with disto-lingual roots: review and clinical management. IntEndod J 2012;45:963-78.

\author{
guidelines,American association of endodontists, \\ accessed 20.07.2016. Available \\ from:http://www.aae.org/dentalpro/guidelines.htm \\ 56.Standards of practice,Canadian academy of \\ endodontics, accessed 20.07.2016. Available \\ from:http://www.caendo.ca.
}

